\title{
KARDINALE ASPEKTE VAN NASIONALE DIENSPLIG MET SPESIFIEKE VERWYSING NA SUID-AFRIKA
}

\author{
Kmdt C.J. Nöthling*
}

This article reviews the cardinal aspects of universal military service (conscription) with specific reference to the South African situation, and against the backdrop of military service in what the author terms as the 'international community'. In his introduction he discusses the evolution of compulsory military service in the briefest terms, and then proceeds to a comparative overview of the subject within the international framework. It is averred that military service in most Western countries (and especially those in NATO) compares most unfavourably with induction in the forces of Warsaw and the Peoples' Republic of China. There are a few notable exceptions, however, viz Switzerland (which pursues an effective policy of armed neutrality), Israel and the Republic of South Africa. Comparing the 'average' Soviet and South African soldier, he concludes that while the Russian counterpart is the submissive product of an austere system, the South African soldier is a more balanced combination of self-discipline and initiative. This implies that even the military system is only fractional, and to a large extent reflects the rules of society. On this premise he takes a closer look at National Service as a system influenced by the community. In this respect attention is given to four cardinal aspects, viz economy, age groups, military dissenters and volunteers. Although accepting the notion of critics that the national economy in South Africa could be adversely affected by (any) system of extended service, he claims - with historical inference - that the new system will alleviate the individual's obligations. The part dealing with the induction of older men is a brief study in comparative history and carries the notion that not only young men can play the game called 'war'. The author views the growing phenomenon of military dissent (or resistance to military service) in the Western countries with concern, and comments that this pacifist attitude can and will be exploited by radical movements with political objectives. This is the case with organizations such as the South African Liberation Support Committee (SALSCOM) which aims to undermine the South African Defence Force, thereby paving the way for a communist take-over in the Republic of South Africa. As to the final aspect, viz volunteers, the view is expounded that in the face of an external threat (or in actual conflict) no country can rely on a system of voluntary military service. In his final analysis the author concludes that as the calibre of men produced by a particular military system is always an indication of the efficiency of such a system, National Service in South Africa should be judged in positive terms: the South African soldier, being a product $O_{i}^{R}$ an effective military system, ranks among the best in the world.

\section{Inleiding}

Wanneer militêre diensplig ter sprake kom, word 'n veelheid fasette in die samelewing belig. In die moderne gemeenskap is dit 'n verskynsel wat nie bloot in die konteks van nasionale sekerheid opgeteken staan nie, maar vertolk moet word in terme van die individu (en die sosiale ordening waarin hy hom bevind) se totale bestaan. As sodanig hou dit velerlei implikasies in, onder meer die uitwerking daarvan op die sosio-ekonomiese bedeling van ' $n$ staat.

Die nuwe Wysigingswet op Verdediging het dié onderwerp opnuut in die Suid-Afrikaanse ge- meenskap ter sprake gebring as 'n strydvraag met vele standpunte. Teenoor die positiewe gesindheid van diegene wat die nasionale sekerheid van die Republiek bo persoonlike belange stel, is daar ook die negatiewe en skeptiese gees waarin dit in sommige kringe bevraagteken is. In hierdie opsig het die plaaslike media die kwessie van Nasionale Diensplig dan ook op grond van uiteenlopende en selfs botsende gesigspunte ter sprake gebring; in sommige koerante is dit selfs in ' $n$ wyer politieke perspektief geplaas, onder andere in die Rand Daily Mail van 24 Maart 1982: 'They (South Africa's business leaders) urged the Government to produce 
positive answers to the thorny political issues which form part of the defence problem.'

In sakekringe was die reaksie insgelyks uiteenlopend, ofskoon daar ' $n$ algemene konsensus was dat die hersiening van Nasionale Diensplig in beginsel aanvaar moes word. 'Kenners van die Suid-Afrikaanse ekonomie het gister die nuwe dienspligstelsel in beginsel gesteun maar het gemeen die uitwerking daarvan op die private sektor gaan straf wees en het gemaan dat dit omsigtig toegepas moet word', berig Ingo Capraro in Beeld van 24 Maart 1982. In sekere gemeenskappe was die algemene houding daarteenoor eensydig veral waar dit aan politieke interpretasies gekoppel is.

Dit val nie binne die perspektief van hierdie artikel om enige uitsprake te lewer oor die meriete van standpunte met betrekking tot die nuwe dienspligstelsel nie. Nietemin word die mening gehuldig dat dié onderwerp nie uitsluitlik aan die hand van eietydse, unieke omstandighede (sosio-ekonomies, polities, strategies, ens) sinvol vertolk kan word nie. Enersyds moet dit gesien word in 'n historiese konteks van ontwikkeling en andersyds moet dit op ' $n$ vergelykende basis teen ' $n$ universele agtergrond ontleed word. In samehang hiermee word die soeklig veral laat val op die implikasies wat diensplig vir die enkeling - die soldaat - inhou.

Die ondersoekmetode wat hier aangebied word, hou enigsins verband met ' $n$ algemene waarneming, $\mathrm{nl}$ dat diensplig ondanks die feit dat dit na die unieke vereistes van elke volk georden en geskik word, in die internasionale spektrum wesenlike raakpunte van ooreenkomste vertoon en veral wat die individuele militêre persoon - die soldaat - se persoonlike welvaart betref. Dié truïsme word met besondere insig toegelig in Windrow en Wilkinson se werk The Universal Soldier: 'The soldier is shaped far more by the nature of the society which bears him than by the experience of soldiering itself ... Nevertheless, the profession of arms is one of those callings which set a man rather emphatically apart from the attitudes of the mass of his contemporaries on certain narrow aspects of life; and for all that he is a creature of his time, he has more in common with soldiers of other ages and nations than his own civilian brothers in his reactions to certain situations. ${ }^{11}$

Op grond van hierdie aanname word in dié artikel gepoog om die verhouding van soldaat en diensplig histories te verantwoord en vervolgens tot sekere gevolgtrekkings met betrekking tot die huidige bestel in Suid-Afrika te geraak.

\section{Agtergrond}

Krygsdiens as ' $n$ inherente aspek van oorlog is ' $n$ metgesel van die geskiedenis van enige land. Militêre diensplig hier te lande is so oud soos die volksplanting self.

Militêre diensplig het reeds so lank terug as 2700 v.C. in die dae van die Egiptiese koninkryk bestaan, ofskoon dit tot in die agtiende eeu selektief in die kader van die lewenslange beroep (bv huursoldate) aan die orde van die dag was. Die eerste werklike formele ordening daarvan deur proklamasie en wetgewing op universele grondslag in die Westerse gemeenskappe is betreklik resent; so byvoorbeeld is dit eers laat in die agtiende eeu in die Franse Republiek ingestel. $^{2}$

Tussen 1807 en 1813 is ' $n$ dienspligstelsel in Pruisse ontwikkel wat as grondslag en model vir die meeste Europese volke gedien het. Ná die Napoleontiese tydperk het die Pruisse dié stelsel vootgesit sodat hulle tydens die oorlog met Frankryk (1870-1871) 'n groot leër in die veld kon stoot vergeleke met Frankryk wat oorwegend op 'n klein professionele leër staatgemaak het. $^{3}$ Interessant is die feit dat Frankryk ná sy verpletterende nederlaag in 1871 algemene militêre diensplig heringestel het.

Gedurende die negentiende eeu het die gebruik om burgerlikes vir krygsdiens op te roep, algemeen in Europa posgevat. In navolging van die Europese model, is diensplig ook gedurende die Amerikaanse Burgeroorlog (1861-1865) in die Verenigde State ingestel. ${ }^{4}$ In die geskiedenis van Suid-Afrika was dit veral die 'burgermilisiestelsel' met sy beginsel van persoonlike diensplig, soos dit deur Kaapse Vryburgers na die binneland uitgedra is, wat vermelding verdien. Dit was die begin van die sogenaamde 'kommandostelsel' wat later met soveel welslae in die Boererepublieke toegepas is. Ná Uniewording is die beginsel van persoonlike diensplig dan ook by wyse van wetgewing (Wet no 13 van 1912) vasgelê. Dié beginsel het ook in latere aanvullende en vervangende wetgewing ná 1957 (toe die nuwe Verdedigingswet, Wet no 44 van 1957 aanvaar is) behoue gebly. 


\section{Diensplig in die Internasionale gemeenskap}

Drie lande in die Vrye Wêreld waar diensplig tans toegepas word en as sodanig bewys lewer as 'n effektiewe oplossing teen (moontlike) eksterne aanslae, is Suid-Afrika, Israel en Switserland. Wat eersgenoemde twee lande betref, kan gewys word op die feit dat die aanvanklike dienspligtydperk in Israel oor drie jaar strek vergeleke met twee jaar in die geval van Suid-Afrikaanse burgers. In die geval van Switserland is die aanvanklike dienspligtydperk ietwat korter, dog kennis moet geneem word van die feit dat vanweë dié land se beleid van gewapende neutraliteit, heelwat klem gelê word op konstante paraatheid.

Hierteenoor vertoon die dienspligstelsels (waar dit wel voorkom) in die meeste Westerse lande 'n minder gunstige prentjie. In 'n Navo-land soos Wes-Duitsland, wat voortdurend in die skaduwee leef van sy kommunistiese buurstate in OosEuropa, is die verpligte dienstydperk slegs 15 maande. ${ }^{5}$ Dit vergelyk nietemin goed met diensplig in België waar die jonger broers diensplig heeltemal kan vryspring indien die oudste broer 12 maande in die weermag gedien het. In Brittanje en die Verenigde State word tans geen diensplig toegepas nie en word staandemagelemente deur ' $n$ stelsel van vrywillige diens aangevul.

In hierdie verband kan die meeste Westerse lande nouliks met die kommunistiese lande in die Warskouverdrag vergelyk word. In die SowjetUnie, wat in die praktyk ' $n$ algemene lotingstelsel toepas, ondergaan 80 persent van die manlike bevolking militêre diensplig ${ }^{6}$ - 'n merkwaardige syfer indien in ag geneem word dat dié land 'n bevolking van oor die 260 miljoen het. Dieselfde patroon word in sy satellietstate (Oos-Duitsland, Hongarye, Pole ens) aangetref waar die aanvanklike dienspligtydperk 24 maande en langer kan wees. In die Chinese Volksrepubliek kan die aanvanklike dienspligtydperk wissel tussen 3 en 5 jaar. $^{\text {? }}$

Die reële situasie van die dienspligtige word egter slegs ten dele deur wetlike bepalings beskryf. So byvoorbeeld kan verdere toeligting deur die toepassing van militêre dissiplinêre kodes verskaf word. Die feit dat 'n Suid-Afrikaanse burger net soos sy Russiese eweknie aan 'n aanvanklike dienspligtydperk van 24 maande onderworpe is, bied ten beste slegs 'n basis vir vergelyking, en 'n getrouer beeld van hul relatiewe gesteldheid kom eers aan die lig as na hul opleiding self gekyk word. In hierdie verband kan met enkele opmerkings volstaan word:

- In teenstelling met die Suid-Afrikaanse dienspligtige, word die jong Rus wat diensplig moet ondergaan reeds tydens die aanvang van sy diensplig gekonfronteer met 'n element van bestrawwing wat duidelik in die aflê van die militêre eed aan hom voorgehou word: 'Should I break my solemn oath, may the severe penalties of Soviet Law, and the overall hatred and contempt of the working classes strike me. ${ }^{18}$

- Waar die Suid-Afrikaanse dienspligtige heelwat vryheid van beweging en tydsbesteding gegun word (bv vakansieverlof van drie weke en deelname aan sportbyeenkomste), is die Russiese dienspligtige feitlik heeltyds ingeperk: vakansieverlof word by wyse van uitsondering verleen, soos wanneer hy buitengewoon presteer het.

- Wat ander diensvoorwaardes betref, vergelyk die Suid-Afrikaanse dienspligtige uiters goed met sy Russiese eweknie. Eersgenoemde is byvoorbeeld finansieel aansienlik beter daaraan toe as die Russiese dienspligtige wat die maandelikse ekwivalent van tussen R5 en R10 in soldy ontvang. ${ }^{9}$

- Onderwyl daar in die opleiding van die SuidAfrikaanse soldaat meer klem gelê word op selfdissipline en esprit $d^{\prime}$ corps, is die Russiese dienspligtige onderhewig aan ' $n$ strawwe militêre gedragskode. In 'n studie oor die profiel van die Russiese soldaat wys Christopher Donelly onder meer op die feit dat 'n dienspligtige strafbaar sou wees selfs al sou hy nie enige bepaling van die wet oortree het nie. So kan 'n persoon selfs vir blote onbekwaamheid gestraf word! ${ }^{10}$

Ofskoon militêre kenners soos Regis $\mathrm{P}$. Sheehan en andere dit eens is dat diensplig in die magte van die Warskouverdragslande in baie opsigte strawwer is as in dié van die meeste Westerse lande, huldig hulle tereg die mening dat geen vorm van Spartaanse opleiding noodwendig as 'n kriterium vir operasionele doeltreffendheid geld nie. Dit kan trouens gestel word dat ' $n$ meer 'verligte' benadering tot diensplig (soos dit wel in Wes-Europese lande die geval is) in sekere opsigte ' $n$ groter mate van buigsaamheid het wat die vereistes van moderne oorlogvoering betref. So byvoorbeeld is die Russiese soldaat veelal ondergeskik aan 'n dominante bevelskanaal wat min ruimte vir individualisme, vindingrykheid en inisiatief laat. Gevolglik vertolk hy 'n passiewe rol en is hy traag om verantwoordelikheid te aanvaar. 
Daar is egter sekere aspekte ten opsigte waarvan diensplig in Westerse lande nie gunstig met diensplig in lande soos die Sowjet-Unie en die Chinese Volksrepubliek vergelyk nie. In 'n werk getiteld The Chinese Armed Forces Today lewer die Amerikaanse Militêre Inligtingsdiens as volg kommentaar oor die vermoë van die Chinese soldaat: 'The average soldier is a hard and willing worker and is able to survive and improvise under a variety of conditions... He surpasses the average Western soldier in his ability to bear extraordinary hardships ... He has a strong sense of obedience and under competent leadership will attempt to carry out his mission, regardless of obstacles and consequences. The Chinese soldier is considered one of the most highly motivated soldiers in the world today. ${ }^{11}$

Hierdie lofwaardige beeld van 'n kommunistiese soldaat in 'n era van moderne oorlogvoering kontrasteer skerp met die profiel van die Amerikaanse dienspligtige gedurende die oorlog in Viëtnam. Slegs een negatiewe aspek hiervan wat deur Gabriel en Savage in Crisis in Command bespreek word, is die volstrekte weiering om te veg: 'Concurrently an equally ominous indicator of military disintegration became public - 'combat refusals'. In more rigorous armies, such incidents would have been called mutiny - which in fact they were ... in 1970 there could have been as many as 245 such 'refusals' to fight. Without official data, we can only infer that if the progressive and symptomatic military disintegration evidenced by desertions and assassinations of leaders is also reflected in mutinous outbreaks, the number of mutinies was probably quite large. $^{12}$

Onder hierdie besprekingspunt is kortliks aangedui in welke mate bestaande dienspligstelsels in die Westerse wêreld vergeleke met dié in kommunistiese lande sekere tekortkominge openbaar. In dié verband is militêre profiele kwalitatief vergelyk op grond van die aanname dat die doeltreffendheid van 'n bepaalde dienspligstelsel/stelsel van opleiding gemeet kan word aan die kaliber soldaat wat dit lewer. Vervolgens word gelet op die verhouding tussen die dienspligtige en die maatskaplike bedeling. Hierby word die openbare mening betrek.

\section{Diensplig en die gemeenskap}

In 'n land soos Suid-Afrika, waar diensplig universeel is en dus ' $n$ nasionale karakter vertoon, is dit vanselfsprekend dat die gemeenskap - waar-

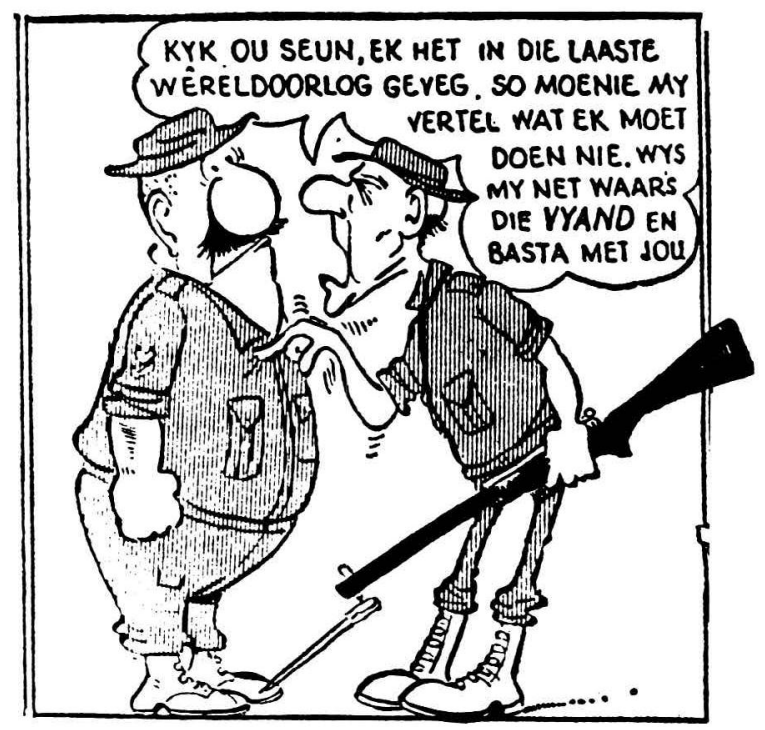

Die nuwe Nasionale Dienspligstelsel, waardeur diensplig tot hoër ouderdomsgroepe uitgebrel is, het in die SuidAfrikaanse pers ook tot heelwat humoristlese uitsprake en voorstellings aanleiding gegee. Hierdie spotprent deur C. Marais het in DIE VOLKSBLAD verskyn.

uit die dienspligtige kom - tot op groot hoogte inspraak in dié aangeleentheid sal hê. Die aanvaarbaarheid en eindelike welslae van 'n dienspligstelsel sal derhalwe ook in 'n groot mate deur die houding van die gemeenskap bepaal word.

In hierdie verband kom etlike besprekingspunte ter sprake waarvan slegs enkeles hier aangesny word ter illustrasie, $\mathrm{nl}$ ekonomiese faktore, ouderdomsgroepe, dienspligontduiking en vrywilligers. Dié faktore is gekies omdat hulle as besonder relevant tot die Suid-Afrikaanse situasie beskou word.

\section{Ekonomiese faktore}

Die algemene beswaar van sakelui en nyweraars dat die nuwe Nasionale Dienspligstelsel 'n akute arbeidsprobleem sal vererger, is reeds in die inleiding vermeld. Dat sodanige aansprake 'n mate van geldigheid bevat, kan nie betwyfel word nie, dog kennis moet geneem word van die feit dat die verspreiding van die verdedigingslas oor 'n breër spektrum van mannekrag inderdaad ook tot 'n verligting van die arbeidsprobleem in sekere sektore kan bydra.

Dit is interessant om daarop te let dat werkgewers gedurende die Tweede Wêreldoorlog oor die onttrekking van mannekrag uit arbeidsektore vir deelname aan die oorlog aanvanklik sterk verdeeld was. Die aanspraak dat die Suid-Afrikaanse ekonomie daardeur geskaad sou word, 
was egter totaal ongegrond. Trouens, vanweë die geweldige tekorte aan gebruiksgoedere wat tydens en ná die oorlog ontstaan het, was SuidAfrika een van die talle lande wat 'n ongekende ekonomiese opbloei in die handel en die nywerheid ondervind het.

Een saak wat aandag verdien, is die aansprake van ekonomies onafhanklike persone en veral boere van wie 'n groot aantal in die kommando's dien. Wat die nuwe wetgewing betref, het die vise-president van die Suid-Afrikaanse Landbou-unie, mnr Kobus Jooste, dan ook tereg opgemerk dat dit aansienlike verligting in die boerderygemeenskap teweeggebring het. ${ }^{13} \mathrm{En}$ kele positiewe aspekte wat hier ' $\mathrm{n}$ rol sal speel, is die feit dat die versterking van die Kommandomag die enkeling se verdedigingslas verminder, en tweedens die gebiedsgebondenheid van kommando's in veral plattelandse gebiede. Dit sal meebring dat boere wat militêre verpligtinge het, in die toekoms vir korter periodes van hul plase afwesig sal wees en in die geval van gebiedsgebonde diens 'n ogie oor hul boerderybelange kan hou.
Deur die nuwe wetgewing is ' $n$ netelige probleem wat histories teruggevoer kan word na die bewind van die Hollands Oos-Indiese Kompanjie bevredigend opgelos. Die historiese kronologie hiervan word onder die hoof van dienspligontduiking vollediger toegelig en vireers kan net gemeld word dat die omvang van dié probleem relatief groter was in 'n tyd toe die landbou die vernaamste bestaansekonomie was.

\section{Ouderdomsgroepe}

Ingevolge die nuwe wetgewing is 'n breër spektrum van ouderdomsgroepe in die Nasionale Dienspligstelsel betrek waarvan die detail nie hier bespreek word nie. Van wesenlike belang is egter die feit dat hierdie wetlike bepalings om verskeie redes (bv vanweë verkeerde vertolkings) besware in sommige kringe uitgelok het.

Indien dié aangeleentheid as historiese parallel met die verlede ondersoek word, kom interessante en insiggewende raakpunte na vore. So was dit juis 'n akute mannekragprobleem in die

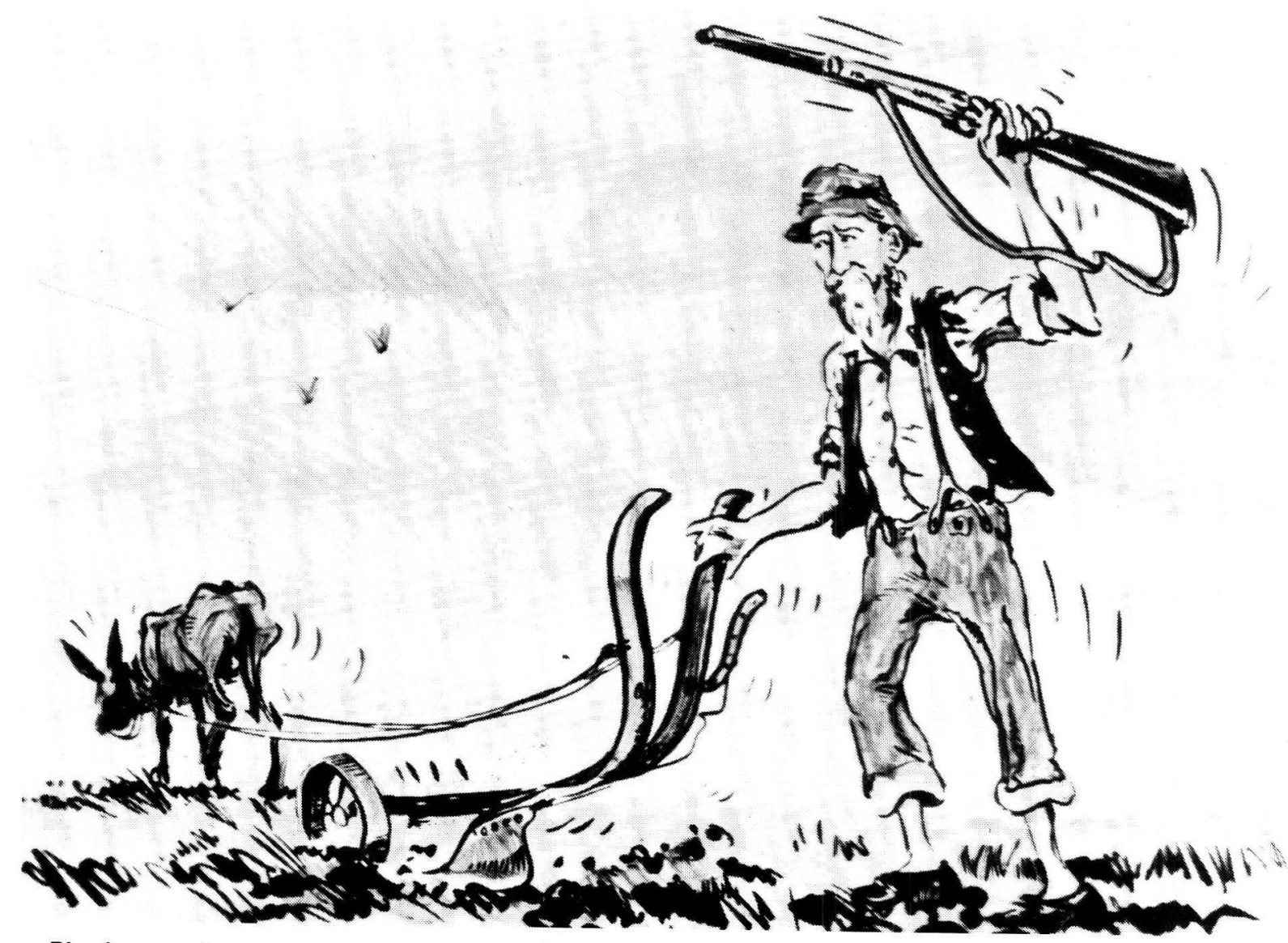

Die ploeg en die roer - 'n simboliese blik op die Suid-Afrikaner se wordingsgeskiedenis in 'n tydperk toe arbeid en selfverdediging deel van sy daaglikse bestaan was 
geledere van die Republikeinse magte in die Tweede Vryheidsoorlog - tesame met die vyand se numeriese oormag - wat vrywilligers in haas alle ouderdomsgroepe die wapen laat opneem het. Sommige vrywilligers was jong penkoppe, kwalik ouer as agt jaar, terwyl ander so oud as 75 jaar was. ${ }^{14}$

Hierdie vrywilligers (!) het ongeag die feit dat hulle nie dienspligtig was nie, genoeg moed aan die dag gelê om die ongerief van koue winters in die oop veld te ontbeer en om hul lewens ter wille van hul vaderland in die gevaar te stel. Van hulle het dan ook baie op die slagveld gesneuwel terwyl ander in krygsgevangekampe omgekom het.

Hierdie somber greep uit die wordingsgeskiedenis van Suid-Afrika mag op die oog af as onbeduidend met betrekking tot die huidige tydsgewrig voorkom. Die feite van die omstandighede waarin Suid-Afrika hom tans bevind mag verskil, dog is sy dilemma nie veel anders nie:

- Britse imperialisme is vervang deur Russiese neo-kolonialisme wat uitlewing vind deur kommunistiese terroriste-aanslae op Suid- en Suidwes-Afrika.

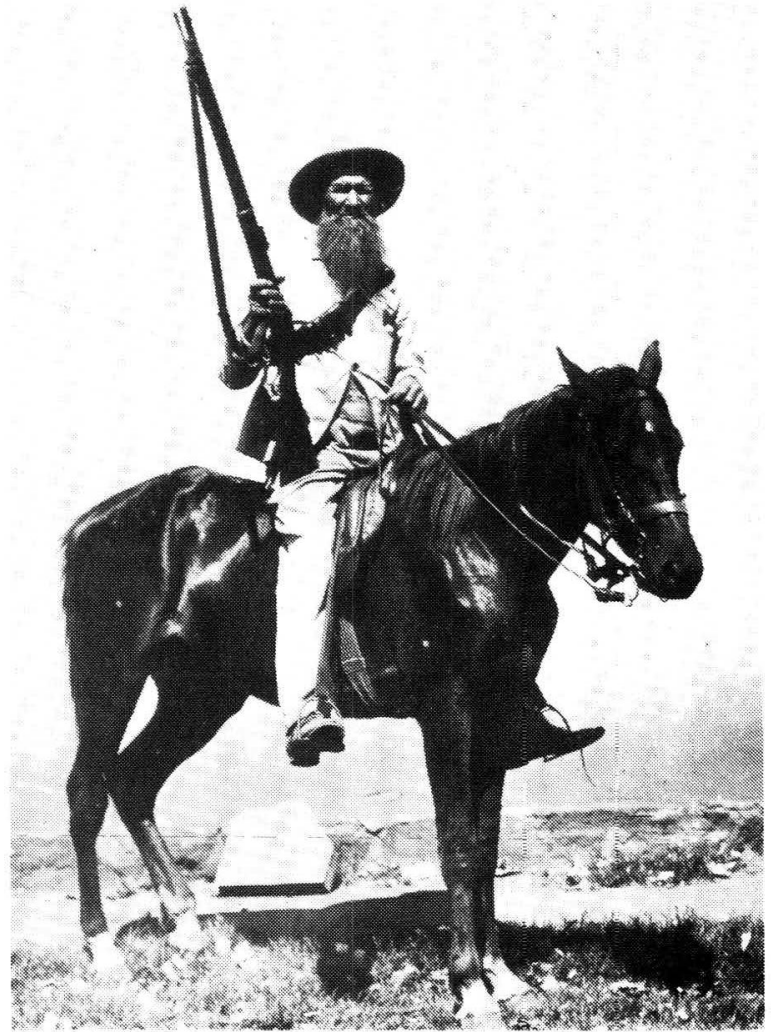

Ná die uitbreek van die Tweede Vryheidsoorlog het talle ou veterane van tot 75 jaar as vrywilligers in die Boeremagte geveg

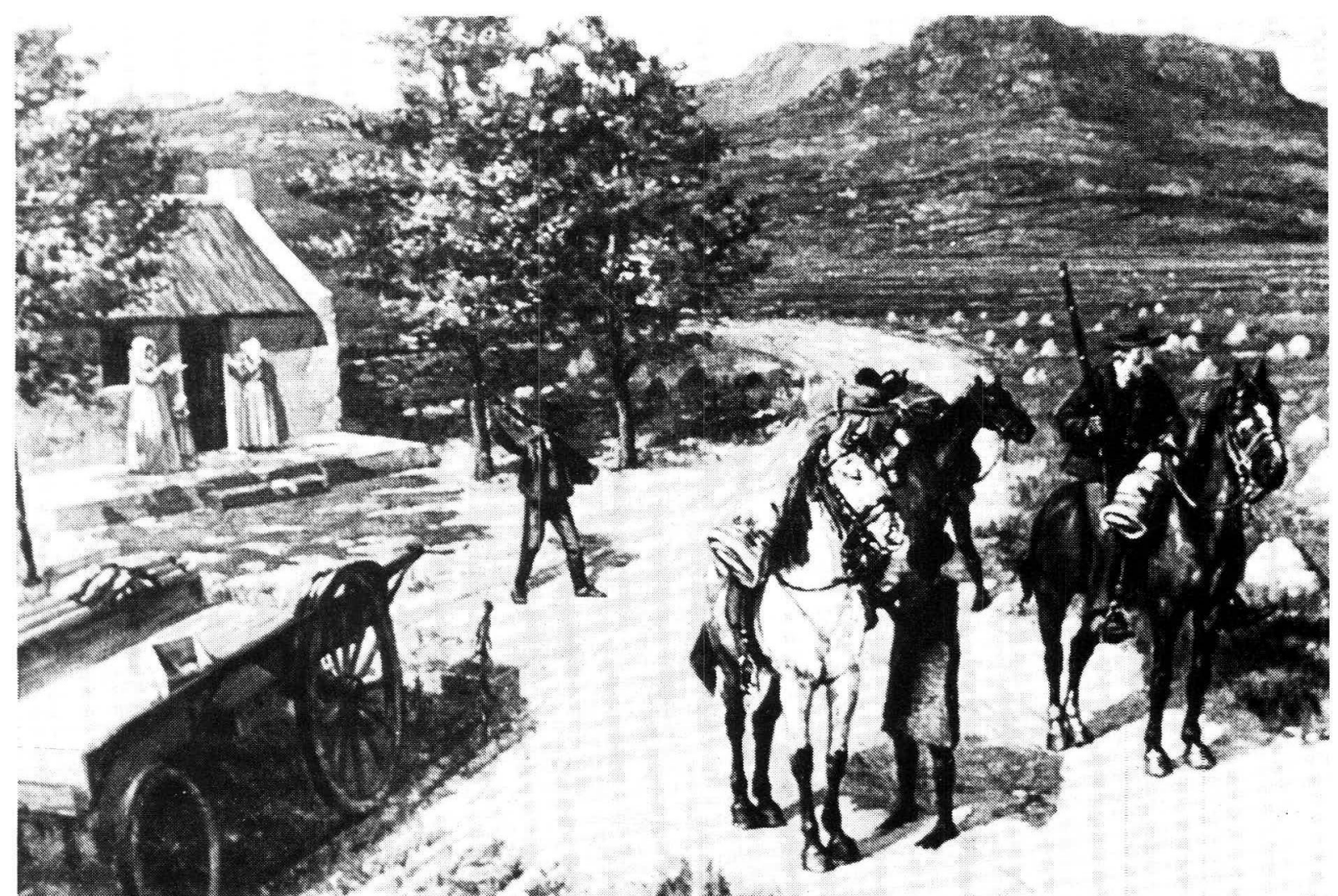

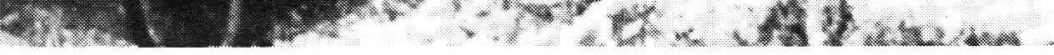

Die kunsskilder E.J. Austin se voorstelling 'Die laaste burger van die huisgesin' - 'n historiese uitbeelding van 'n jong seun wat in die Tweede Vryheidsoorlog sy ouerhuis verlaat om by 'n Boerekommando aan te sluit. Dié kunswerk vorm deel van die Fehr-versameling in Kaapstad 


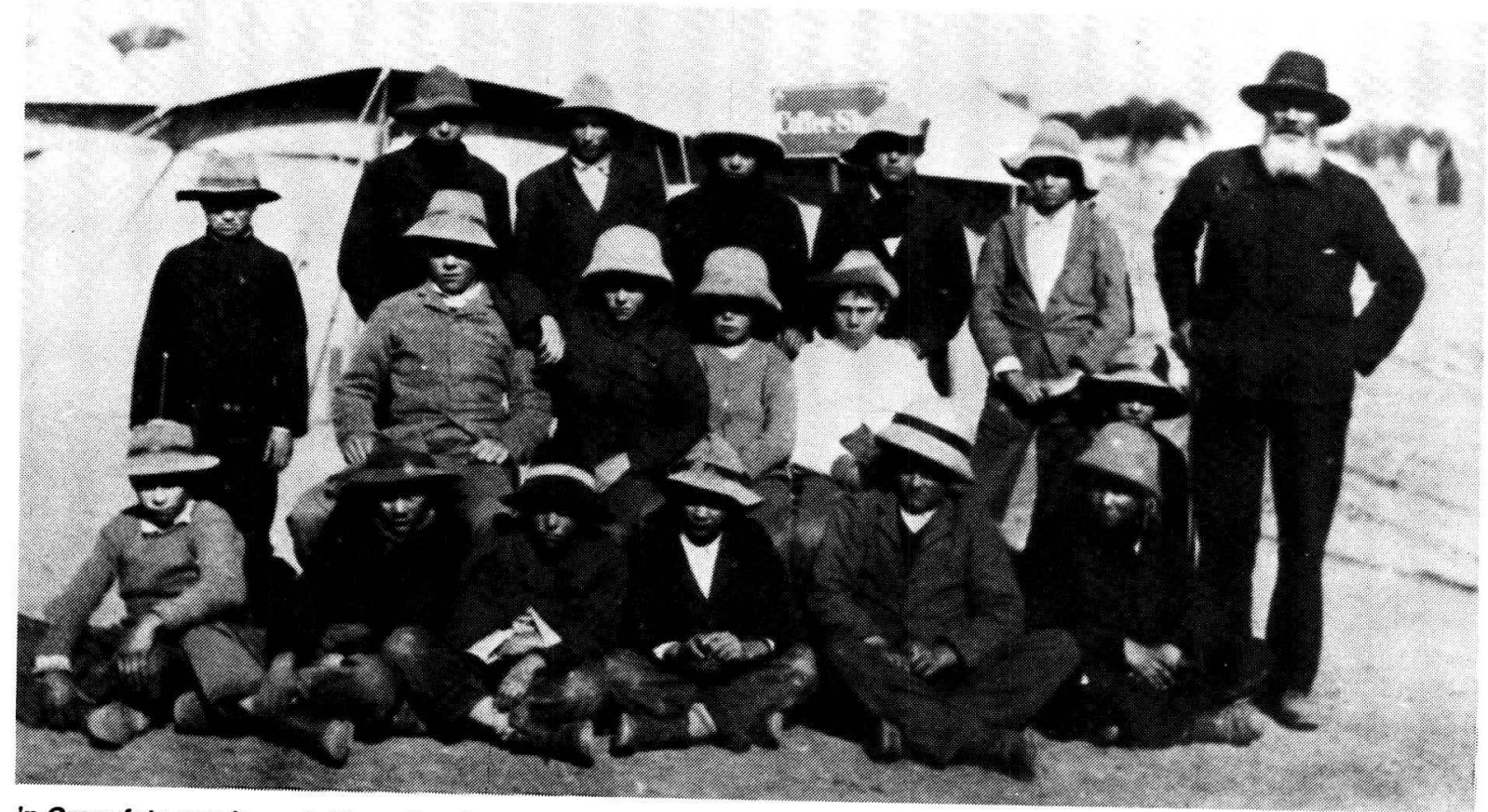

'n Groepfoto van 'n aantal jeugdige Boerekrygers wat gedurende die Tweede Vryheidsoorlog gevange geneem en na 'n krygsgevangekamp in Indië gestuur is. Hulle ouderdomme wissel tussen 8 en 14 jaar

- Westerse moondhede in die Vrye Wêreld is nie bereid om in Suider-Afrika militêr teen Russiese ekspansionisme op te tree nie en die Republiek van Suid-Afrika sal soos die twee Boere-republieke van destyds op homself aangewese wees vir die handhawing van sy nasionale sekerheid.

- Suid-Afrika se militêre paraatheid word deur 'n mannekragprobleem aan bande gelê.

In hierdie verband dien vermeld te word dat die groter belading van die Kommandomag genoodsaak is omdat nie genoeg vrywilligers in die verlede na vore gekom het om in die kommando's te dien nie.

\section{Dienspligontduiking}

Beriggewing oor dienspligontduiking moet in 'n universele verband beskou word. As verskynsel is dit so oud soos die geskiedenis van oorlog self hoewel dit veral sedert die Amerikaanse Burgeroorlog in die 19de eeu sterk op die voorgrond getree het. ${ }^{15}$ In die resente era het dit in Westerse lande soos die VSA, Brittanje en Australië selfs op 'n georganiseerde grondslag voorgekom onder die vaandel van pasifisme. Sodanige bewegings het met slagspreuke soos 'wars will cease when men refuse to fight' in samewerking met radikale groepe en die media ' $n$ groot aan- deel gehad in die uiteindelike afskaffing van diensplig in die Verenigde State. ${ }^{16}$

Daarteenoor is pasifisme in kommunistiese lande 'n seldsame verskynsel. In lande soos die Sowjet-Unie en die Chinese Volksrepubliek is die algemene publiek besonder postief ingestel teenoor diensplig wat as 'n groot voorreg beskou word. In The Chinese Armed Forces Today word onder meer die volgende vermeld: 'The prominence and respect which the armed forces have enjoyed in recent years have enhanced the prestige and social standing of the soldier and have overcome the traditional contempt for military life of earlier years. It is a proud family whose son or daughter is chosen for service in the PLA. ${ }^{17}$

Die probleem van dienspligontduiking in SuidAfrika is ook nie van resente oorsprong nie. Dit kan hoofsaaklik teruggevoer word na die feit dat persoonlike materiële belange tot aan die einde van die negentiende eeu by die (potensiële) dienspligontduiker swaarder geweeg het as patriotisme en die belange van sy gemeenskap. In 'n era toe ekonomiese bedrywighede in SuidAfrika om die landbou gesentreer het en plundertogte deur swart stamme aan die orde van die dag was, het blanke boere nie altyd kans gesien om aan lang strafekspedisies weg van hul plase af deel te neem nie. Gedurende die Tweede Vryheidsoorlog was blanke boerderye dan ook die skyf van Kitchener se gehate veld- 
tog van 'verskroeide aarde' - 'n veldtog wat baie burgers uit die kommando's laat dros en na hul plase laat terugkeer het. $^{18}$

Soos reeds vermeld, staan Suid-Afrika vandag in 'n algeheel nuwe sosio-ekonomiese bedeling en die oorsake van dienspligontduiking moet op ander terreine gesoek word. In hierdie opsig speel radikale elemente met politieke oogmerke 'n leidende rol. Plaaslike groepe word onder meer bygestaan deur verbode organisasies met kommunistiese affiliasies soos byvoorbeeld die South African Liberation Support Committee (SALSCOM) en die South African Military Refugee Aid Fund (SAMRAF). Die doelstellings van eersgenoemde organisasie blyk duidelik uit die volgende verklaring wat dit in 1978 uitgereik het: 'The major priority we see for Salscom at this point is to proceed with the military project that was initiated by Salscom members in Okhela ... The South African Defence Force will become the key to the survival of the present regime (sic)

In general the South African state is able at this stage to boast what appears to be a welloiled war machine... The absolute loyalty of the members of the military and their willingness to defend the system with their lives is an essential contribution to maintaining the system ... Salscom thus sees one of its priorities in providing a support base outside South Africa ... The Deserters' Programme aims at assisting refugees of the military and to publicise this assistance to generate a flow of deserters that in its own right will establish the first clear precedent inside South Africa of a widespread move of dissension within the ranks. ${ }^{19}$

Ondanks die pogings van dié organisasies om diensplig in Suid-Afrika te ondermyn, het die voorkoms van dienspligontduiking in die SuidAfrikaanse Weermag - in watter vorm ook al - in die afgelope 4 jaar afgeneem. Die redes hiervoor is velerlei, maar soos SALSCOM self te kenne gee, hou die welslae van die Suid-Afrikaanse Weermag grootliks verband met die absolute lojaliteit van die Suid-Afrikaanse soldaat teenoor sy land. Een faktor wat hier 'n deurslaggewende rol speel, is die openbare mening wat onsimpatiek teenoor dienspligontduikers staan. Die veragting waarmee dienspligontduikers bejeen word, herinner enigsins aan die sosiale verwerping van diegene wat gedurende die Tweede Vryheidsoorlog hul militêre verpligtinge ontduik het.

\section{Vrywilligers}

Een belangrike oorweging wat in die konsipiëring vandie nuwe Nasionale Dienspligstelsel gegeld het, was die feit dat die mannekragsituasie in die Suid-Afrikaanse Weermag nie na wense was nie. Daar is onder meer gevind dat die aantal persone wat as vrywilligers na vore gekom het om in veral die Kommandomag te dien, nie aan die gestelde sterktes voldoen het nie.

In die verlede het stelsels van vrywillige diens onbevredigend en ondoeltreffend geblyk te wees. Sy byvoorbeeld het die werwing van vrywilligers in Brittanje kort ná die uitbreek van die Eerste Wêreldoorlog so 'n laagtepunt bereik dat verpligte militêre diens as alternatief oorweeg is. In 1916 was die Britse regering dan ook genoodsaak om militêre diensplig by wyse van wetgewing in te stel. ${ }^{20}$ Die Britse dilemma in 1914 het duidelik getoon dat die Verenigde Koninkryk se militêre onvermoë veral ten opsigte van opgeleide mannekrag grotendeels te wyt was aan die stelsel van vrywillige diens wat tot in daardie stadium in swang was. Op grond hiervan kan die stelling gemaak word dat geen land ' $n$ stelsel van vrywillige diens in die aangesig van 'n vyandelike bedreiging of aanslag kan handhaaf nie. Daarom is ' $n$ dienspligstelsel soos dit tans in die Republiek van Suid-Afrika die geval is, die enigste alternatief.

In die Tweede Vryheidsoorlog het 'n groot aantal vrywilligers van verskillende nasionaliteite (lere, Franse, Duitsers, Skandinawiërs, Italianers, ens) aan Boerekant geveg. In die huidige internasionale politieke klimaat is dit allermins ' $n$ faktor waarop Suid-Afrika in ' $n$ komende konflik sal kan reken.

Terselfdertyd kan gewys word op die feit dat lede van die ander bevolkingsgroepe in die Republiek (wat nie aan diensplig onderworpe is nie) wel in die Suid-Afrikaanse Weermag (kan) dien deur byvoorbeeld by die Staande Mag aan te sluit. In hierdie sin kan hul bydrae tot die verdedigingstaak ook as vrywillig beskou word. Die belangrike rol wat hierdie mense in die verdediging van die Republiek speel, kan ook nie onderskat word nie; dit beklemtoon die noodsaak aan 'n vrywilligerelement wat in die nasionale aspirasies van die totale bevolking deel. Dit was sulke aspirasies wat die Kaapse rebelle gedurende die Tweede Vryheidsoorlog genoop het om hul lot by dié van die twee Boere-republieke in te werp. 


\section{Slotsom}

In hierdie oorskouing is die nuwe Nasionale Dienspligstelsel aan die hand van enkele aspekte - wat as van kardinale belang geag word - binne die raamwerk van die internasionale spektrum bespreek. Dit was nie soseer die skrywer se doel om die noodwendigheid van diensplig aan te toon nie, maar eerder om dit in die konteks van moderne oorlogvoering aan die hand van historiese verwysings te verantwoord.

By wyse van evaluering kan tot die volgende gevolgtrekkings geraak word:

- Teen die agtergrond van die internasionale magsbalans, wat 'n skerp verskil in die benadering tot diensplig in die Westerse lande en die kommunistiese wêreld aandui, is enkele state soos Israel en Suid-Afrika genoodsaak om hul militêre paraatheid deur beproefde en buigsame dienspligstelsels te handhaaf. Indien daar gelet word op die huidige stand van sake ten opsigte van diensplig in die meeste Westerse lande, is die algemene indruk verontrustend.

- Verder is aangetoon dat bedenkinge wat uit- gespreek is oor die nuwe Dienspligstelsel, grotendeels ongegrond is. Onder meer is daarop gewys dat die verdedigingslas nou regmatig versprei word wat vir die enkeling 'n regverdiger bedeling skep.

- Weerstand teen diensplig soos byvoorbeeld deur dienspligontduiking, kan op die lange duur die slagvaardigheid van 'n land ernstig benadeel. In hierdie verband speel die openbare mening ' $n$ uiters belangrike rol en moet daarteen gewaak word dat pasifistiese bewegings en radikale groepe met politieke motiewe nie die militêre bestel en die funksie van nasionale verdediging ondermyn nie.

- Die doeltreffendheid van 'n dienspligstelsel wat die faset van opleiding insluit - kan gemeet word aan verskeie faktore, maar enige finale analise sal die kaliber soldaat (dienspligtige) wat dit voortbring, skerp in fokus plaas. Dit blyk dat diensplig in die kommunistiese wêreld besonder geslaagd is, terwyl dit in die Westerse lande kommer wek. In hierdie opsig is Suid-Afrika een van die min uitsonderings: die Suid-Afrikaanse soldaat, synde die produk van 'n effektiewe dienspligstelsel, vergelyk baie goed met die bestes ter wêreld.

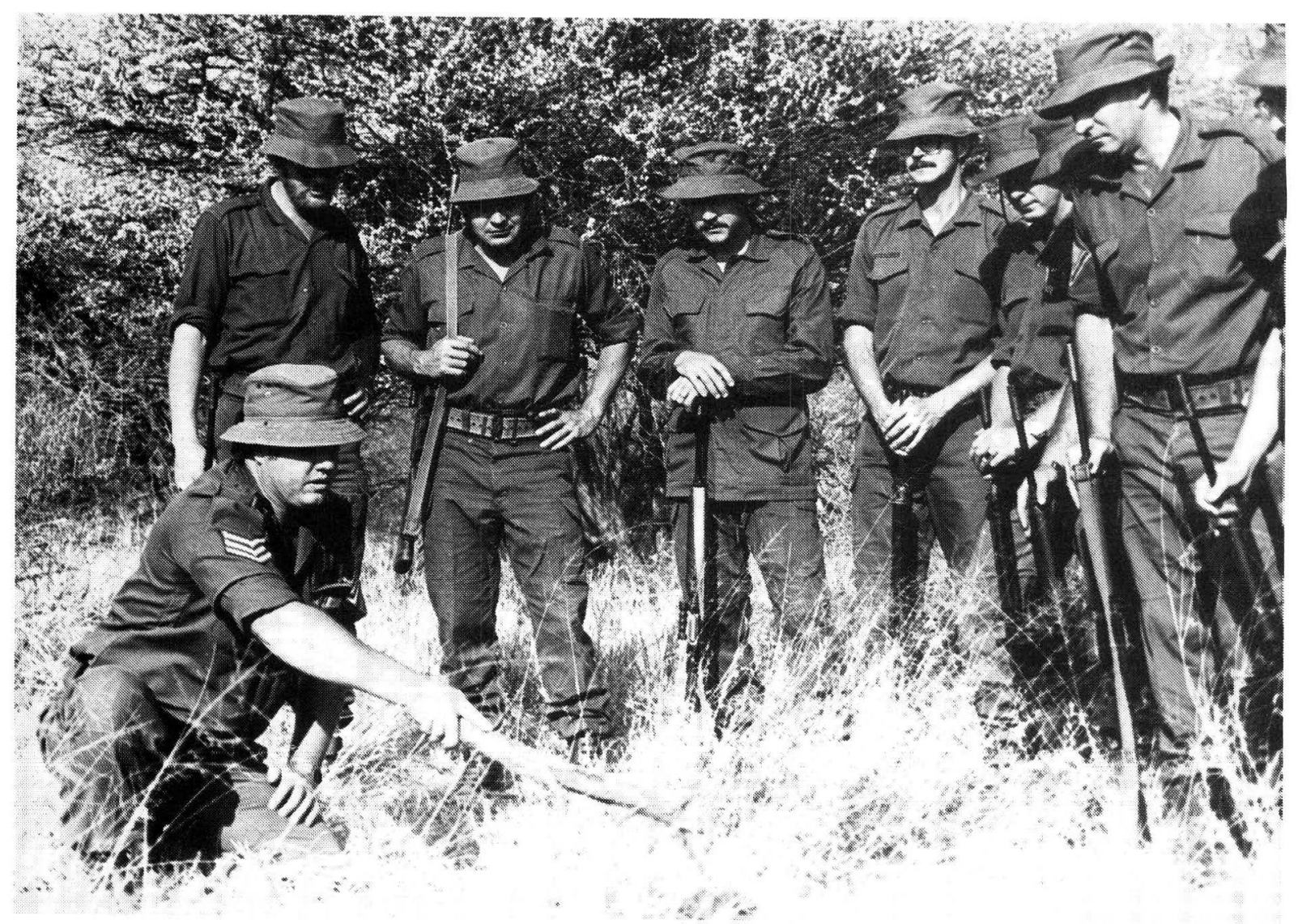

Lede van die Suid-Afrikaanse Leër word in operasionele opleiding voorgelig. Die opleidingspeil van Suid-Afrikaanse soldate word as van die hoogste ter wêreld beskou 
* Kmdt C.J. Nöthling, MA, is verbonde aan die Militêre Informasieburo van die SAW.

\section{Verwysings}

1. Windrow, M., en F. Wilkinson, The Universal Soldier, Guinness, Middlesex $1971, p g$

2. Prasad, D., en T. Smythe, Conscription: A World Survey, War Resisters International, London 1968, p 37. Militêre diensplig is in 1793 in Frankryk ingestel.

3. Ibid, p 45. Universele diensplig in Duitsland is in 1870 ingestel, dws dieselfde jaar waarin die Duitse Ryk tot stand gekom het. Met die ontwapening van Duitsland ná die Eerste Wêreldoorlog is dit in 1918 opgehef maar weer in 1934 tydens die bewind van Adolf Hitler heringestel.

4. Ibid, p 139. Diensplig is in 1863 in die Noordelike en Suidelike State ingestel. Ná die Amerikaanse Burgeroorlog is dit afgeskaf maar weer in 1917 heringestel en twee jaar later weer afgeskaf. In 1940 is diensplig opnuut ingestel, deur verdere wetgewing in 1948 uitgebrei en eers weer in 1973 algeheel afgeskaf.

5. Federale Republiek van Wes-Duitsland: The Force Structure in the Federal Republic of Germany (Report to the Federal Government), 1972/73, p 13
6. Collins, J., American and Soviet Military Trends Since the Cuban Missile Crisis, Center for Strategic and International Studies, Washington D.C. 1978, pp 50-57.

7. Verenigde State van Amerika: The Chinese Armed Forces Today, U.S. Defense Intelligence Agency \& Arms and Armour Press, Londen 1979, p 121.

8. Sheehan, R.P., 'The Soviet soldier: A Spartan in the Age of Aquarius', Marine Corps Gazette Vol 62 No 10, Oktober 1978, p 36.

9. Donelly, C., 'The Soviet Soldier', British Army Review No 55, April 1977, p 33.

10. Ibid, p 34.

11. Verenigde State van Amerika: The Chinese Armed Forces Today, 0120.

12. Gabriel, R.A., en P.L. Savage, Crisis in Command, Hill \& Wang, New York 1978, p 45.

13. 'Wet los boerdery se groot probleme op', Paratus Vol 33 No 7, Julie 1982, p 30.

14. Van der Walt, A.J.H., J.A. Wiid et al, Geskiedenis van Suid-Atrika, (Deel 1), Nasionale Boekhandel, Kaapstad 1951, p 551 et seq.

15. Brock, P., Twentieth-Century Pacifism, Van Nostrand Reinhold, New York 1970, pp 1-13.

16. Ibid, $\mathrm{p} 248$

17. Verenigde State van Amerika: The Chinese Armed Forces Today, $\mathrm{p} 120$.

18. Van der Walt en Wiid, op cit, pp 592-596.

19. 'Salscom: Trying to Seduce SA Defence Force from Abroad', To the Point 17 Maart 1978, p 15.

20. Brock, P., op cit, p 15. 